\title{
DRUG RESISTANCE IN SCHISTOSOMIASIS: A REVIEW
}

\section{JOHN I. BRUCE*, LUIZ CANDIDO DE SOUZA DIAS**, YUNG-SAN LIANG* \& GERALD C. COLES***}

\author{
* Center for Tropical Diseases, University of Lowell, Lowell, Massachusetts 01854, USA ** Instituto de \\ Biologia, Universidade de Campinas, 13081 Campinas, SP, Brasil *** Department of Zoology, University of \\ Massachusetts, Amherst, Massachusetts 01003, USA
}

Drug resistance associated with the treatment of human schistosomiasis appears to be an emerging problem requiring more attention from the scientific community than the subject currently receives.

Drug-resistant strains of Schistosoma mansoni have been isolated by various investigators as a result of laboratory experimentation or from a combination of field and laboratory studies. Review of this data appears to indicate that the lack of susceptibility observed for some of the isolated strains cannot be ascribed solely to previous administration of antischistosome drugs and thus further studies are required to elucidate this phenomena.

Strains of S. mansoni have now been identified from Brazil which are resistant to oxamniquine, hycanthone and niridazole; from Puerto Rico which are resistant to hycanthone and oxamniquine; and from Kenya which are resistant to niridazole and probably oxamniquine. Strains derived by in vitro selection and resistant to oxamniquine and possibly to oltipraz are also available. All of these strains are currently maintained in the laboratory in snails and mice, thus providing for the first time an opportunity for indepth comparative studies. Preliminary data indicates that $\mathrm{S}$. haematobium strains resistant to metrifonate may be occurring in Kenya. This problem could poise great difficulty in the eventual development of antischistosomal agents.

Biomphalaria glabrata from Puerto Rico and Brazil were found to be susceptible to drugresistant $\mathrm{S}$. mansoni from each country.

Drug resistance can be defined as the transitory or permanent loss of the initial sensitivity of microorganisms or mammalian cells to the effect of substances which interfere with vital functions of these structures. It manifests itself after the exposure to the agent in vitro or in vivo. More recent developments in this area might justify a further simplification of this statement in the words of "Lamy" (1967) as the "sudden or gradual, permanent or transient loss of the originally present susceptibility to a chemical compound".

The first observation that certain microorganisms could become resistant to drugs which they were formerly sensitive to was made by Ehlich $(1907,1910)$ for trypanosomes. Subsequently, many microorganisms such as bacteria viruses, spirochetes, fungi, richettsia and protozoa such as malaria, entamebae,

Support for this study was provided in part by the Research Foundation of São Paulo State (FAPESP), Brazil and by Grant No. 1R21-AI-20171-01 from the National Institute of Allergy and Infectious Diseases (NIAID), National Institutes of Health (NIH), United States of Amcrica. coccidians among others were shown to be able to develop resistance to therapeutic agents (Bishop, 1962; Goldstein et al., 1969; Kelly \& Hall, 1979; Peters, 1979; Chapman, 1982). The problem of drug resistance also occurs among arthropods (Brown \& Pal, 1971).

During this century, the widespread use of drugs to treat and control infectious organisms has almost invariably led to the development of drug resistance (Goldstein et al., 1969). In man, this problem has been a very persistant one in regard to the treatment of bacteria and protozoa such as malaria, trypanosomiasis and more recently leishmaniasis (Bishop, 1962). Constant vigilance is maintained for the occurrence of new resistant strains among protozoa and bacteria as compared to no effort for the helminths which infect man.

\section{Drug resistance in helminths (nematodes)}

Among the helminths, drug resistance has occurred from the widespread use of anthelmintics to treat nematode infections in domestic animals. Considerable concern has arisen in the veterinary industry in Australia because of drug 
resistance in nematodes of sheep. The problem has already progressed beyond the situation as reviewed recently by Prichard (1980), to one where in some areas the two major types of anthelmintics used no longer kill some species of nematodes. The phenomenom of nematode drug resistance is not confined to Australia. In the opinion of many scientists, the problem is now growing worse in America.

Based on farmers' experiences with anthelmintics especially in Australia and reports of new cases, the problem with drug resistance in nematodes is likely to persist. In fact, users of nematode anthelmintics are now seeking alternative ways of controlling these drugresistant nematode worms (Anderson \& Waller, 1985).

Drug-resistant strains of nematodes have been produced experimentally (in both in vivo and in vitro systems) in the laboratory with such anthelmintics as carbendazole, thiabendazole, and levamisole (Berger, 1975; Colglazier et al., 1974; Kates et al., 1973; Le Jambre et al., 1976; Lewis et al., 1980). For carbendazole and thiabendazole, resistance has been brought about by selection of a naturally drug-resistant population and the progressive elimination of drug sensitive worms. In the case of levamisole and benzimizole resistance, Caenorhabditis elegans worms were first exposed to a mutagen and then selected with these drugs.

\section{Drug resistance in helminths (trematodes)}

The problem of drug resistance among helminths is not limited only to nematodes. The literature contains many references which refer to the wide variation in results obtained from drug trials both clinically and under experimental conditions concerning the susceptibility of Schistosoma mansoni from various geographical regions. The results of these observations have shown that strains of $S$. mansoni originating from the same region also differ in their sensitivity to antischistosomal drugs (Lee et al., 1971; Mousa et al., 1969; Saoud, 1965; Pedro et al., 1979; Pedro, 1980).

References to the occurrence of resistant $S$. mansoni strains have been reported by various investigators as a result of laboratory experimentation or from a combination of field and laboratory observations. These include the reports by Araujo et al., 1980; Compos et al.,
1976; Dias et al., 1982; Dias et al., 1978; Jasma et al., 1977; Katz et al., 1973; Rogers \& Bueding, 1971. It appears that from some of the reported data that the lack of susceptibility observed in some strains of $S$. mansoni cannot be ascribed solely to previous administration of antischistosome drugs and thus further studies are required to elucidate this phenomena.

Rogers \& Bueding (1971) and Jasma et al. (1977) showed the occurrence of genetically transferred resistance to hycanthone for several strains of $S$. mansoni in mice. It should be pointed out that the relative ease by which resistance to hycanthone was produced under experimental conditions may be due to the highly mutagenic nature of this compound. Development or selection of resistant strains may not occur as readily with other antischisto. somal agents.

Thus it is also important to distinguish between tolerance and resistance. For example, if a population of worms which has not been exposed to a drug does not respond completely, then this can be called tolerance. If on the other hand, the response of a population of worms of one species changes with sucessive uses of the drug, then resistance can be considered to be present. We currently observe both of these occurrences among schistosome populations (Prichard et al., 1980).

The occurrence of drug-resistant $S$. mansoni as a result of treatment of patents was first suggested by Davis (1966) during a program in upper Egypt. It was observed by clinicians that the cure rate was lower in those patients undergoing a second course of treatment with niridazole than in those receiving treatment for the first time, thus suggesting that perhaps drug resistance was developing in the retreated group.

Since that time and until recently, nearly all of the reports concerning information relative to the occurrence of drug resistant $S$. mansoni in the field from patients treated with various drugs have come from Brazil. (Araujo et al., 1980; Compos et al., 1976; Dias et al., 1982; Dias et al., 1978; Katz et al., 1973).

However, during the past 2-3 years studies conducted collaboratively between scientists from Brazil, Kenya and the United States 
have confirmed the existence of drug-resistance in Brazil and found worms which did not respond to oxamniquine in Kenya. In addition, poor cure rates were also found with metrifonate in Kenya suggesting that drug-tolerant $S$. haematobium may be present (Coles et al., 1986). Also, some patients infected with praziquantel were not cured with two separate regimens of praziquantel. Isolation of these strains and their subsequent passage through snails and exposure of mice, which were subsequently treated with praziquantel did not demonstrate drug-resistance to this compund.

\section{Drug tolerant and resistant S. mansoni strains}

An important aspect of our collaborative research has been the establishment of a bank of strains which can be classified as either "tolerant" or "resistant" (Table I). The description for each of these strains of $S$. mansoni is as follows:

1. MPR-1 (University of Michigan - Puerto Rico): This strain has been maintained continuously in the laboratory since 1953 by passage through Biomphalaria glabrata (Puerto Rican strain) and CD-1 swiss albino mice.

2. MAP (Minas Gerais, Brazil; oxamniquine and hycanthone resistant): The MAP strain was obtained from a patient in 1978 following unsuccessful treatment with hycanthone and then oxamniquine. This strain has been maintained continuously in the laboratory by passage through albino $B$. glabrata (Brazilian strain) and CD-1 swiss albino mice.

3. H-30 (Johns Hopkins, Puerto Rico; hycanthone resistant): This strain was derived by in vivo selection in mice treated with hycanthone in 1976 and has been maintained continuously in the laboratory by passage through B. glabrata (Puerto Rican strain) and CD-1 swiss albino mice.

4. MPROXR-1 (University of Massachusetts, Puerto Rico; oxamniquine resistant): This strain was derived by in vitro selection of the MPR-1 strain with oxamniquine and has been maintained continuously in the laboratory by passage through B. glabrata (Puerto Rican strain) and CD-1 swiss albino mice since its selection in 1985.

5. MPROL-1 (University of Massachusetts, Puerto Rico; partially oltipraz-resistant): This strain was derived by in vitro selection of the MPR-1 strain with oltipraz and has been maintained continuously in the laboratory by passage through B. glabrata (Puerto Rican strain) and CD-1 swiss albino mice since its selection in 1985.

6. BH (Belo Horizonte, Minas Gerais, Brazil; drug susceptible): This strain was isolated from an untreated patient in 1967 and has been maintained continuously in the laboratory by passage through albino B. glabrata (Brazilian strain) and CD-1 swiss albino mice.

Each of these strains are currently maintained at the Center for Tropical Diseases, University of Lowell. The MAP and BH strains are also maintained at the Department of Parasitology, State University of Campinas.

\section{Stability tests}

The response of the drug-susceptible, tolerant and resistant strains (Table I) to several antischistosomal drugs were recently tested to determine their stability and the results are shown in Tables II and III.

\section{TABLE I}

Tolerant and resistant strains

\begin{tabular}{lcc}
\hline Strain & Tolerant & Resistant \\
\hline MPR-1 & $\mathbf{X}$ & \\
KMN-1 & $\mathbf{X}$ & \\
MAP & & X \\
H-30 & & X \\
MPROXR-1 & & X \\
MPROL-1 & & X \\
BH* & & \\
\hline
\end{tabular}

* Reference strain which is susceptible to six of the most recently developed antischistosomal agents.

The BH strain (Table II) was found to be susceptible to all of the antischistosomal agents used. Nearly all worms found were observed to be dead in the liver as compared to the control (untreated) mice where all worms found were alive. Oogram changes showed nearly maximal alteration as compared to control (Untreated) animals which showed no changes. 
TABLE II

The activity of some schistosomicides against a brazilian strain $(\mathrm{BH})$ of Schistosome mansoni

\begin{tabular}{|c|c|c|c|c|c|c|c|c|}
\hline \multirow{2}{*}{ Drug } & \multirow{2}{*}{$\begin{array}{c}\text { Dose } \\
(\mathrm{mg} / \mathrm{kg})\end{array}$} & \multicolumn{2}{|c|}{ No. of mice } & \multirow{2}{*}{$\begin{array}{c}\text { Mean } \\
\text { worm } \\
\text { burden }\end{array}$} & \multicolumn{2}{|c|}{ Worm recovery $(\%)$} & \multirow{2}{*}{$\begin{array}{l}\text { Dead } \\
\text { worms in } \\
\text { liver }(\%)\end{array}$} & \multirow{2}{*}{$\begin{array}{c}\text { Oogran } \\
\text { change } \\
(\%)\end{array}$} \\
\hline & & Treated & Examined & & Liver & M. veins* & & \\
\hline Control & - & 15 & 13 & 52.1 & 22.8 & 77.2 & 0.0 & 0.0 \\
\hline Hycanthone & $1 \times 80$ & 15 & 9 & 36.2 & 98.1 & 1.9 & 97.2 & 100.0 \\
\hline Oxamniquine & $1 \times 100$ & 15 & 14 & 33.3 & 94.8 & 5.1 & 96.4 & 100.0 \\
\hline Amoscanate & $1 \times 300$ & 15 & 13 & 35.8 & 94.8 & $5: 1$ & 99.3 & 100.0 \\
\hline Niridazole & $5 \times 100$ & 15 & 13 & 37.6 & 96.0 & 4.0 & 93.8 & 92.3 \\
\hline Oltipraz & $5 \times 125$ & 15 & 12 & 28.4 & 100.0 & 0.0 & 100.0 & 100.0 \\
\hline Praziquantel & $5 \times 100$ & 15 & 11 & 29.2 & 100.0 & 0.0 & 100.0 & 100.0 \\
\hline
\end{tabular}

All animals were sacrificed at 14 days after dosing.

* $\mathrm{M}$. veins $=$ mesenteric veins.

TABLE III

The activity of some schistosomicides against 5 strains of Schistosome mansoni

\begin{tabular}{|c|c|c|c|c|c|c|c|c|c|}
\hline \multirow{2}{*}{ Strain } & \multirow{2}{*}{ Drug } & \multirow{2}{*}{$\begin{array}{c}\text { Dose } \\
\text { (mg/kg) }\end{array}$} & \multicolumn{2}{|c|}{ No. of mice } & \multirow{2}{*}{$\begin{array}{c}\text { Mean } \\
\text { worm } \\
\text { burden }\end{array}$} & \multicolumn{2}{|c|}{ Worm recovery $(\%)$} & \multirow{2}{*}{$\begin{array}{c}\text { Dead } \\
\text { worms in } \\
\text { liver }(\%)\end{array}$} & \multirow{2}{*}{$\begin{array}{c}\text { Oogram } \\
\text { changes } \\
(\%)\end{array}$} \\
\hline & & & Treated & Examined & & Liver & M. veins $* *$ & & \\
\hline \multirow{3}{*}{ MAP } & Hycanthone & $1 \times 80$ & 15 & 10 & 37.6 & 9.7 & 90.3 & 46.7 & 0.0 \\
\hline & Oxamniquine & $1 \times 100$ & 15 & 10 & 39.6 & 15.6 & 84.3 & 0.0 & 0.0 \\
\hline & Contiol & - & 15 & 13 & 48.0 & 23.6 & 76.4 & 0.0 & 0.0 \\
\hline \multirow{3}{*}{ MPR-1 } & Oxamniquine & $1 \times 100$ & 15 & 13 & 21.1 & 29.0 & 70.9 & 0.0 & 0.0 \\
\hline & Praziquantel & $5 \times 100$ & 15 & 14 & 17.0 & 00.0 & 0.0 & 80.0 & 100.0 \\
\hline & Contral & - & 15 & 12 & 22.2 & 17.2 & 82.8 & 0.0 & 0.0 \\
\hline \multirow{2}{*}{ H-30 } & Hycanthone & $1 \times 80$ & 15 & 15 & 28.2 & 22.5 & 77.5 & 1.5 & 6.7 \\
\hline & Control & 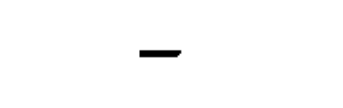 & 15 & 12 & 30.0 & 23.4 & 76.5 & 0.0 & 0.0 \\
\hline \multirow{2}{*}{ MPROXP } & Oxamniquine & $1 \times 100$ & 15 & 13 & 24.5 & 5.0 & 95.0 & 33.3 & 0.0 \\
\hline & Control & - & 15 & 14 & 26.6 & 14.3 & 85.7 & 0.0 & 0.0 \\
\hline \multirow{3}{*}{ MPROL } & Oltipraz & $5 \times 125$ & 15 & 15 & 9.0 & 23.8 & 76.2 & 93.0 & 70.0 \\
\hline & Oltipraz & $1 \times 300^{*}$ & 15 & 15 & 2.1 & 00.0 & 0.0 & 56.2 & 100.0 \\
\hline & Control & - & 15 & 15 & 25.8 & 18.6 & 81.4 & 0.0 & 0.0 \\
\hline
\end{tabular}

* Sacrificed on day 56 after dosing; all others sacrificed at 14 days after dosing.

** M. veins = mesenteric veins.

The MPR-1 strain (Table III) was found to be still resistant to oral treatment with oxamniquine but susceptible to praziquantel. Oogram changes showed maximal alteration for praziquantel treated mice as opposed to no observed alterations for the oxamniquine treated and control (untreated) mice.

The KMN-1 strain (Table I) which is resistant to niridazole was not included in this study.

The MAP strain (Table III) was found to be still resistant to hycanthone and oxamniquine, as previously reported, with no observed alterations in oogram patterns for treated or control (untreated) mice.
Resistance of the $\mathbf{H}-30$ strain to hycanthone was sustained (Table III), as previously reported (Jasma et al., 1977), with very slight alteration in oorgram patterns observed for the treated mice and none for control mice.

Following treatment with oxamniquine, the MPROXR strain (Table III) was found to be very resistant; its stability being maintained with no oogram changes observed in either the treated or control (untreated) mice, as previously reported.

The MPROL strain (Table III) was observed to be susceptible to oral treatment with 125 $\mathrm{mg} / \mathrm{kg}$ of oltipraz per day $X 5$ and at a regimen 
of $300 \mathrm{mg} / \mathrm{kg} \mathrm{X} 1$ day it was apparently more resistant as judged by migration of worms from mesenteries to liver and by oogram changes.

The BH strain was found to be susceptible to hycanthone, oxamniquine, niridazole, amoscantate, oltipraz and praziquantel. This data is very important because it is essential that a strain known to be susceptible to the currently used antischistosomal drugs is available for evaluating novel compounds as well as for comparing resistant and susceptible strains.

The MPR-1 strain which is resistant to oxamniquine was isolated in the field (Dr. Henry van der Schalie obtained the MPR.1 strain form Dr. Paul Thompson to the Park Davis Pharmaceutical Company in 1953) before hycanthone or oxamniquine were introduced clinically. Apparently, resistante developed as passage through mice and snails occurred without the strain ever having encountered the drug. Alterations of isoenzyme patterns have been reported following passage of schistosome strains in mice (Coles, 1971; LoVerde et al., 1985) and the present results indicate that changes in susceptibility to a particular drug could also conceivably occur, although when and how rapidly it occurred is not known.

With suitable modifications, it should be possible to use the recently developed method of in vitro selection of Coles \& Bruce (1987) to look for a small percentage of worms tolerant to a schistosomicide, and therefore predict whether resistance might develop on prolonged routine passage of the strain in the laboratory.

Susceptability of Biomphalaria to drug-resistant S. mansoni

An important aspect of schistosome drugresistance which needs addressing is the potential of specific snail-intermediate host strains to transmit and disseminate the resistant parasite regionally and geographically in the field. Preliminary studies have been carried out comparing the susceptibility of a strain of Biomphalaria glabrata from Brazil to one from Puerto Rico.

The data obtained is shown in Table IV. It is shown that infections did occur with the drug-resistant strains suggesting that resistance could travel with movement of people who were not cured following therapy. Movement of breeding stock has been suggested as one method in the spread of drug-resistant ovine nematodes (Brenner, 1974).

\section{Discussion and Conclusion}

Based on results obtained thus far from Kenya and Brazil, we feel that in order to demonstrate resistance in a population of schistosomes, it will first be necessary to determine the response to several isolates of worms in laboratory animals to antischistosome agents before the drugs are used on a wide scale. The occurence of significant changes in response to a drug following widespread use in a particular area is an indication that resistance has occurred. Isolates failing to respond to antischistosomal drugs should be considered as naturally tolerant isolates until such time as sufficient data is available to confirm that resistance has occurred.

In one of our recent publications Coles et al. (1986), we have recommended that standardized protocols be required for use in the demonstration of schistosome resistance so that data from different laboratories and regions can be compared. These recommendations are as follows: Outbred mice should be given a cercarial dose so that it will produce little or no mortality. By tail immersion, this usually means 80 to 100 cercariae per mouse. At six to eight weeks after infection groups of at least six mice are dosed orally with drug suspended in $25 \%$ glycerol and $1 \%$ Cremophor. Mice are examined post-mortem and the numbers and conditions of worms and the oogram changes noted in control and treated mice. The results are expressed as percentage reduction intreated groups compared to controls. The time of post-mortem should allow for the death of all drug-damaged worms and we recommend mice be sacrificed 14 days after treatment with oxamniquine and praziquantel and 56 days with oltipraz.

In view of the current situation, there seems to be little reason to think that the same problem is not occurring in other regions of the world where antischistosome drugs are being used to treat patients both in clinics and on a mass scale. 
TABLE IV

Susceptibility of Biomphalaria glabrata from Brazil and Pucrto Rico to different strains of Schistosoma mansoni

\begin{tabular}{|c|c|c|c|c|c|c|c|c|c|}
\hline \multirow{3}{*}{$\begin{array}{l}\text { Snail } \\
\text { strain }\end{array}$} & \multirow{3}{*}{$\begin{array}{c}\text { Schistosome } \\
\text { strain }\end{array}$} & \multicolumn{8}{|c|}{ Days of infection } \\
\hline & & \multicolumn{2}{|c|}{ Deaths } & \multicolumn{2}{|c|}{$\begin{array}{l}\text { Shedding } \\
\text { cercariae }\end{array}$} & \multicolumn{2}{|c|}{ Deaths } & \multicolumn{2}{|c|}{$\begin{array}{l}\text { Shedding } \\
\text { cercariae }\end{array}$} \\
\hline & & No. & $\%$ & No. & $\%$ & No. & $\%$ & No. & $\%$ \\
\hline Brazilian & $\begin{array}{l}\text { BH } \\
\text { MAP } \\
\text { H-30 } \\
\text { MPROL } \\
\text { MPROXR } \\
\text { Control }\end{array}$ & $\begin{array}{l}4 \\
1 \\
0 \\
0 \\
0 \\
0\end{array}$ & $\begin{array}{l}8 \\
2 \\
0 \\
0 \\
0 \\
0\end{array}$ & $\begin{array}{r}0 \\
11 \\
0 \\
0 \\
0 \\
0\end{array}$ & $\begin{array}{r}0 \\
22 \\
0 \\
0 \\
0 \\
0\end{array}$ & $\begin{array}{r}21 \\
11 \\
1 \\
1 \\
1 \\
0\end{array}$ & $\begin{array}{r}42 \\
22 \\
2 \\
2 \\
0 \\
0\end{array}$ & $\begin{array}{r}41 \\
29 \\
8 \\
5 \\
4 \\
0\end{array}$ & $\begin{array}{r}82 \\
58 \\
16 \\
10 \\
8 \\
0\end{array}$ \\
\hline $\begin{array}{l}\text { Puerto } \\
\text { Rican }\end{array}$ & $\begin{array}{l}\text { BH } \\
\text { MAP } \\
\text { Control }\end{array}$ & $\begin{array}{l}0 \\
1 \\
1\end{array}$ & $\begin{array}{l}0 \\
2 \\
2\end{array}$ & $\begin{array}{l}0 \\
4 \\
0\end{array}$ & $\begin{array}{l}0 \\
8 \\
0\end{array}$ & $\begin{array}{r}43 \\
17 \\
0\end{array}$ & $\begin{array}{r}86 \\
34 \\
0\end{array}$ & $\begin{array}{r}45 \\
46 \\
0\end{array}$ & $\begin{array}{r}90 \\
92 \\
0\end{array}$ \\
\hline
\end{tabular}

Note: Lach exposure group contained 50 snails.

Although the rate of occurrence of drugresistant strains will depend on the lenght of the parasite life cycle and the selection pressure used, this in turn will depend on the percentage of the population treated, the frequency of dosing and the efficacy of the treatment. Drugs with 100\% efficacy should not select for resistance, but in practice few treatments for schistosomiasis give a complete cure of egg production. Whether those worms that survive are present due to the pharmacology of the schistosomicide and thus the effectiveness of the therapy varying between patients, or because of a natural variation in susceptibility of worms to drugs is not known. If all cases were duc to the former reason, there would be no reason for concern, but if the latter is true, then drug-resistance could be expected to emerge. In practice, both situations may be expected to occur in the field.

There is at present no information on the significance of drug-resistance in schistosomiasis anywhere in the world. Clearly this situation must be remedied as resistance could become a very serious problem in the control of schistosomiasis. Before detailed cpidemiology of resistance can be undertaken, as has been performed for nematodes of sheep, basic information necds to be collected. This must include a description of what resistant strains already exist in the field and to what drugs these strains are resistant. This is a prerequisitc for the optimal clinical therapy of patients harboring resistant strains. It also needs to be determined whether strains failing to respond to more than one type of drug are present. This has been described in the nematode Haemonclus controtus in Austrailia (Prichard et al., 1980) and may be widespread. It could presumably occur with schistosome species as well.

In addition to searching for resistance and trying to relate cure rates to presence of drugresistant worms, we should look for alternative methods to be used for infection of snails with eggs from patients. Current procedures take at least 12 weeks to complete and require large numbers of animals. Alternative tests using infected snails, cercariae or schistosomula should be investigated.

As stated previously, observations concerning tolerance to $S$. haematobium have now been made (Coles et al., 1986). Only one laboratory study, Hsu et al. (1963) suggests drug-resistance may occur with $S$. japonicum worms.

In view of the occurrence of drug-resistant schistosomes following treatment of patients with hycanthone, oxamniquine, niridazole, and metrifonate, it is conceivable that this could occur with compounds which may be developed in the future. This problem then poses great difficulty in the eventual development of antischistosomal agents. 


\section{ACKNOWLEDGEMENTS}

We are gratcful to Mr David A. Boyd and Ms Deborah M. Russell for their valuable technical assistance, and to Ms Allison M. Howard for typing the manuscript.

\section{REFERENCES}

ANDERSON, N. \& WALLER, J., 1985. Resistance in nematodes to antheimintic drugs. Commonwealth Scientific and Industrial Research Organization, Australian Division of Animal Health. Australian Wool Corporation (Series: A ustralian Wool Corporation Technical Publication).

ARAUJO, N.; KATZ, N.; DIAS, E. P. \& SOUZA, C. P., 1980. Susceptibility of chemotherapeutic agents of strains of Schistosoma mansoni isolated from treated and untreated patients. Am. J. Trop. Med. Hyg. . 29: 890-894.

BERGFR, J., 1975. The resistance of a field strain of Haemonchus contortus to five benzimidazole anthelmintics in current use. J. S. Aft. Vet. Assoc., 46: $369 \cdot 372$.

BISHOP, A., 1962. Chemotherapy and drug resistance in protozoal infections. A general outline, $1 \mathrm{~N}$ : Drugs, parasites and hosts, Littles Brown \& Co., Boston, pp. 98-115.

BRENNFR, S., 1974. The genetics of Caenorhabditis elegans. Genetics. 77: 71-94.

BRWON, A. W. A. \& PAL, R., 1971. Insecticide resistance in arthropods. WHO Monograph Series No. 38, 2nd ed.. Geneva.

CHAPMAN, H. D., 1982. Anticoccidial drug resistance, IN: The biology of the coccidia, Ed. Long, P. I., University Park Press. Baltimore.

COLES, G. C., 1971. Alteration of Schistosoma mansoni malate dehydrongenase isoenzymes on passage in the laboratory. Comp. Biochem. Physiol., 40B: $1079-1083$

COLES. G. C.; BRLCE, J. I.; KINOTI, G. K.; MUTAHI, W. T.; DIAS, E. P. \& KATZ, N., 1986. Drug resistance in schistosomiasis. Trans. $R$. Soc. Trop. Med. Hyg. 80: 347 .

COLES, G. C. \& BRUCE, J. I., 1987. In vitro selection of drug resistant Schistosoma mansoni. Int'l. J. Parasit., 17: 767-771

COLGLAZIER, M. L.; KATES, K. C. \& ENZIE, F D., 1974. Carbendazole-resistant Hoemonchus contortus in sheep. J. Parasit., 59:169-174.

COMPOS, R.; MOREIRA, A. A. B.; SETTE JR., H.; CHAMONE, D. A. F. \& SILVA, L. C., 1976. Hycanthone resistance in a human strain of Schistosoma mansoni. Trans. R. Soc. Trop. Med. Hyg., 70: 261-262.

DAVIS, A., 1966. Field trials of ambilhar in the treatment of urinary bilharziasis in school children. Bull. WHO, 35: 827

DIAS, L. C. S.: PEDRO, R. J.: RIGO, E.; GOTO, M. F. F. \& MAFRA, C. L., 1978. Linhagem humana de Schistosoma mansoni resistance a esquistossomicidas. Rev. Saude Publ. S. Paulo, 12:110.

DIAS, L. C. DE SOUZA, PEDRO, R. DE JESUS, \& DEBERALDINA, E. R., 1982. Use of praziquantel in patients with Schistosoma mansoni previously treated with oxamniquine and/or hycanthone resistance of Schistosoma mansoni to schistosomicial agents. Trans. $R$. Soc. Trop. Med. Hyg., 76: 652-659.

EHRLICH, P., 1907. Chemotherapeutische trypanosomen studien. Berlin. Klin Wochschr, 44: 233-236, 280-283, 310-314, 341-344.

EHRLICH, P., 1910. Die grundlagen der experimentellen chemotherapie. A. angew Chem., 23: 2-8.

GOLDSTEIN, A.; ARONOW, L. \& KALMAN, S. M., 1969. Principale of drug action. Harper \& Row Pub. Co., New York, Evanston and London, 78-88.

HSU, S. Y. L.; CHU, J. Y. \& HSU, H. F., 1963. Drug susceptibility of geographic strains of Schistosoma japonicum. Z. Tropenmed. Parasitol. 6: 193; abstracted in Trop. Dis. Bull., 60:1058.

JANSMA, W. B.; ROGERS, S. H.; LIU, C. L. \& BUEDING, E., 1977. Experimentally produced resistance of Schistosoma mansoni to hycanthone. Am.J. Trop. Med. Hyg. 26: 926-936.

KATZ, N.; DIAS, E. P.; ARAUJO, N. \&SOUZA, C. P., 1973. Estudo de uma cepa humana de Schistosoma mansoni resistente a agentes esquistossomicidas. Rev. Soc. Brazil. Med. Trop., 7: 381-387.

KATES, K. C. ; COLGLAZIER, M. L. \& ENZIE, F D., 1973. Experimental development of a carbendazole-resistant strain of Haemonchus contortus in sheep. J. Parasit., 59: 169-174.

KELLY, J. D. \& HALL, C. A., 1979. Resistance of animal helminths to anthelmintics. IN: Advances in Pharmacology and Chemotherapy. Vol. 16, Academic Press, New York.

LAMY, L., 1967. Porh. Biol., 15:1227-1232.

LEE, H. G.; CHEEVER, A. W. \& FAIRWEATHER, W. R., 1971. Influence of parasite strain on chemotherapy of murine schistosomiasis mansoni. Bull. WHO, 45: 147-155.

LE JAMBRE, L. F.; SOUTHCOTT, W. H. \& DASH, K. M., 1976. Resistance of selected line of Haemonchus contortus tothiabendazole, morantel tartrate and levamisole. Int'l. J. Parasit., 6: 217-222.

LEWIS, J. A.; WU, C. H.; LEVINE, J. H. \& BERG, H., 1980. Levamisole-resistant mutants of the nematode Caenorhabditis elegans appears to lack pharmacological acetylcholine receptors. Neuroscience, 5:967.

LOVERDE, P. T.; DEWALD, J.; MINCHELLA, D. J.; BOSSHARDT, S. C. \& DAMIAN, R. T., 1985. Evidence for host-induced selection in Schistosoma mansoni. J. Parasit., 71: 297-300.

MOUSA. A. E.; EL-GAREM, A.; EL-RAZIKY, E. H.; EL-LARIF, A. A.; SELIM, A.; WASSEF, S. A.; HABIB, A. \& EL-SHENAWY, A., 1969. Preliminary studies on prophylaxis, drug resistance, and synergism in experimental schistosomiasis. Ann. New York Acad. Sci., 160:461-485.

PEDRO, R. J.; DIAS, L. C. S.; AMATO NETO, V. \& CARVALHO, S. A., 1979. Observations on the treatment of mansoni schistosomiasis with oxamniquine. Rev. Bras. Pesq. Med. Biol., 12: 207-211.

PEDRO, R. J.; DIAS, L. C. S.; AMATO NETO, V. \& CARVALHO, S. A., 1980. Observations on the treatment of mansoni schistosomiasis with oxamniquine; efficacy in children and in persistent salmonellosis; resistance of a strain of Schistosoma mansoni; hepatic toxicity and neurological side effects. Rev. Inst. Med. Trop. S. Paulo, 22: (Suppl. 4), 32-36.

PETERS, W., 1970. Chemotherapy and drug resistance 
in malaria. Academic Press, New York.

PRICHARD, R. K.; HALL, C. A.; KELLY, J. D. MARTIN, I. C. A. \& DONALD, A. D., 1980. The problem of anthelminthic resistance in nematodes. Asut. Vet. J., 56:239-251.

ROGLR, S. H. \& BUEDING, E., 1971. Hycanthone resistance: Development in Schistosoma mansoni. Science, 172: 1057-1058.

SAOUD, M. F. A., 1965. Comparative studies on the characteristics of some geographical strains of Schistosoma mansoni in mice and hamsters. $J$. Helminth, 39: 101. 